Annals of Warsaw University of Life Sciences - SGGW

Land Reclamation No 43 (1), 2011: 57-69

(Ann. Warsaw Univ. of Life Sci. - SGGW, Land Reclam. 43 (1), 2011)

\title{
Streamflow droughts and probability of their occurrence in a small agricultural catchment
}

\author{
EWA KAZNOWSKA, KAZIMIERZ BANASIK \\ Faculty of Civil and Environmental Engineering, Warsaw University of Life Sciences - SGGW
}

\begin{abstract}
Streamflow droughts and probability of their occurrence in a small agricultural catchment. The goal of this work consists in quantitative analysis of the occurrence of droughts and their occurrence probability estimated for a small agricultural catchment on the basis of a multi-annual series of daily streamflows in the Zagożdżonka river at the Płachty Stare gauging station, in the context of observed changes in the stream regime during the multi-annual period 1963-2010. The Zagożdżonka river catchment is one of a few in Poland, with long-term records on rainfall and runoff. To identify streamflow droughts in daily discharge hydrograms, truncation level $\mathrm{Q}_{90 \%}$ (discharge determined from the flow duration curve) was used. Minimum duration of drought amounting to 10 days, was the additional criterion for identification of droughts. The Nizowka2003 model was used for finding distributions of the probability of deficit volume and duration of maximum summer droughts for the Zagożdżonka river. The droughts in the small agricultural catchment under study concern only summer half-years and most often they are of short duration - up to 20 days. Longer droughts, lasting lightly over 2 months, can be expected - once per 10 years. The occurrence of a summer drought lasting almost all the season in the Zagożdżonka river is probable once per 100 years. A weak correlation between the minimum drought discharge and their duration was found.
\end{abstract}

Key words: streamflow droughts, hydrological drought, probability of non-exceedance.

\section{INTRODUCTION}

More intense and longer droughts have been observed in the last few decades in many regions of the globe. Also in Europe there are areas (in the south) where precipitation has decreased over the 20th century (Kundzewicz et al. 2007). De Luis et al. (2009) detected a decrease in a seasonal and annual precipitation in the east of the Mediterranean Iberian Penisula during the second half of the 20th century. In Poland there is no evidence that the totals for atmospheric precipitation have changed, though an increasing duration of sunshine and consequent evapotranspiration, especially in early summer, have been observed over the few last decades (Górski 2007). However, according to Łabędzki (2006) in the last 25 years droughts in Poland appeared still more frequently, they were more intense and covered important areas of the country. The period from 1982 to 2006 was characteristic for its permanent drought apart of two 4-5-year periods, when the drought did not occur on a larger area of the country (Lorenc et al. 2008). The occurrence of still more frequent and severe droughts bothers especially the agriculture on the Polish Lowland (Kundzewicz et al. 2010). The analysis of the impact of observed changes on the runoff from agricultural catchments requires long series of hydrometric measurements. Multi-annual observations from small catchments of natural character are of special worth (Stahl et al. 2010). It is rather dif- 
ficult to find in Poland small catchments with longlasting observation series. The Zagożdżonka river catchment is one of a few in Poland, with long-term records on rainfall and runoff. Investigation of the records from Płachty Stare (one of the gauging stations) has been conducted by the Department of Hydraulic Engineering of the Warsaw University of Life Sciences since 1963 (Banasik et al. 2009).

When analyzing the droughts identified with hydrological drought one must consider as important not only their duration, deficit volume, and minimum flow size, but also probablility of their occurrence. This information is essential for users of water due to negative effects connected with the occurrence of streamflow droughts, especially on agricultural areas. When a drought occurs, not only water quality goes down but also possibilities of taking the water for the needs of agricultural irrigation decrease. This is important especially for the reason that irrigation in Poland is of intervention character, and it is used in short periods during the growing season, especially in regions with severe and frequent droughts (Labędzki 2009). It is worthy to note that the research on pollution concentration in rivers carried out by Young et al. (1999) on the case of the Thames river watershed, England, showed that the highest concentrations of phosphates covered the periods of low flow occurrences in summer-autumn months, pointing out that the highest phosphate concentrations occurred in relatively dry years. The case was similar in the Zagożdżonka stream catchment where the highest phosphate concentrations concerned the periods with droughts (Kaznowska and Hejduk 2011).
For practical purposes the knowledge on the drought size occurring once for $5,10,25,50$ and 100 years is the most important (Zelenhasič and Salvai 1987), while Chang and Stenson (1990) underline that duration and deficit volume are the two elements of droughts being most important in water management. These two traits show a strong correlation (Zelenhasič and Salvai 1987; Chang and Stenson 1990; Bonacci 1993; Byczkowski et al. 2002; Hong et al. 2007). The Zelanhasič and Salvai model (1987), being used by Nizowka2003 (Jakubowski and Radczuk 2004) computer program, makes possible to define a probability of non-exceedance of the largest streamflow drought duration and the largest streamflow drought deficit.

The goal of this work consists in quantitative analysis of the occurrence of droughts and their occurrence probability estimated for a small agricultural catchment on the basis of a multi-annual series of daily streamflows in the Zagożdżonka river at the Płachty Stare gauging station, in the context of observed changes in the stream regime during the multi-annual period 1963-2010.

\section{MATERIAL AND METHODS}

\section{Description of the research area}

The catchment of the Zagożdżonka river is situated on the Masovian Lowland, that according to Farat et al. (1995) is one of the areas of Poland particularly endangered by the occurrence of hydrological droughts. The Zagożdżonka river is a left-side tributary of the Vistula River and its catchment area truncated with the Płachty Stare gauging station 
amounts to $82.4 \mathrm{~km}^{2}$. The absolute relief to the Plachty Stare gauge is $37 \mathrm{~m}$ (maximum and minimum heights are 185 and $148 \mathrm{~m}$ above the sea level). The average slopes of the main stream are 2.5 to $3.5 \%$, and its valley is narrow and shallow (Byczkowski et al. 2001). The catchment is used mainly by agriculture. The average yearly sum of precipitation in the Zagożdżonka rivulet catchment, as calculated from the multi-annual period 1963-2007 is $605 \mathrm{~mm}$, while the average from the summer half-year $-385 \mathrm{~mm}$, at the variability from about $223 \mathrm{~mm}$ in 1988 to $759 \mathrm{~mm}$ in 1974 (Kaznowska and Banasik 2009). One water-bearing level of quaternary stage occurs generally on the catchment area. The ground water level is free and is formed at the depth from 1 to $12 \mathrm{~m}$ under the ground surface. A close connection exists between surface waters and waters occurring in quaternary formations (Wiencław et al. 1993).

\section{Characteristics of droughts}

The drought is a period when low water levels and streamflows persist in rivers, caused by longlasting lack of precipitation, intensive evaporation (summer droughts) or longlasting frost (winter droughts). The drought can be defined only on the conventional way (Ozga-Zielińska 1990). The most often used definition consists in considering such period as a drought when streamflows are equal to or lower the truncation level of drought. This method is called the threshold level method in the reference literature. A complex method for estimation of drought being identified with hydrological drought is given in the publication Hydrological Drought edited by Tallaksen and Lanen (2004). The discharge determined from the flow duration curve $Q_{90 \%}-0.087 \mathrm{~m}^{3} \cdot \mathrm{s}^{-1}$ was chosen as the threshold level of drought for the need of this research. The size of truncation level $-Q_{90 \%}$ was estimated at the Płachty Stare gauging station for the Zagożdżonka river for the period of 45 years (1963-2007). Minimum duration of drought amounting to 10 days, referred to in the literature as $d_{\min }-$ minimum drought length, was the additional criterion for identification of droughts on daily-recorded hydrographs.

Daily-recorded hydrographs done in hydrological years (from 1 November to 31 October) from the period 19632010 were input data for estimation of droughts. The Nizowka2003 (Jakubowski i Radczuk 2004) model was used to identification of droughts and their quantitative parameters: minimum drought discharge $\left(\mathrm{Q}_{\min , \mathrm{n}}\right)$, duration $\left(\mathrm{T}_{\mathrm{n}}\right)$, and drought deficit volume $\left(\mathrm{V}_{\mathrm{n}}\right)$. The drought occurrence frequency was defined by grouping droughts into duration classes: $10-20,21-30,31-60$, $61-90$, and $\geq 90$ days. The drought occurrence frequency was also defined as the average number of droughts per year from the following formula:

$L_{n}=\frac{\sum n_{i}}{N}$

where:

$\sum n_{i}-$ sum of droughts in N-years period;

$\mathrm{N}$ - number of years in the study period.

A series of the annual minima of $n-$ -day average flow - AM (1-day) as defined from the multi-annual period 1963-2010 was also used to the research 
of long-duration changes in the water regime of the Zagożdżonka river. The number of days with discharges lower than threshold level of drought was identified for each year, with the criterion of minimum length of individual drought episodes being not taken into account.

\section{Drought occurrence probability}

The Nizowka2003 (Jakubowski and Radczuk 2004) model was used for identifying distributions of the probability of deficit volume and duration of maximum summer droughts for the Zagożdżonka river, the model which is the method of describing and analyzing the stochastic process of droughts presented by Zelanhasič and Salvai (1987). For being sure that the analysis would cover only extreme droughts, a low threshold level of drought $-\mathrm{Q}_{90 \%}$ was adopted for their identification on daily-recorded hydrographs, as being recommended by Zelanhasič and Salvai (1987); Tallaksen and Lanen (2004). Only those droughts whose $V_{n}$ deficits were greater than $0.005 \mathrm{~V}_{\max }$ (the deficit volume of the extreme drought found in the multi-annual period 1963-2010) were taken to further analyses. Non-important observations were removed. The Zelanhasič and Salvai (1987) method requires also that the droughts under analysis were independent. Fulfilling of that criterion was possible thanks to adoption of an assumption that droughts distant to each other with less than $t_{\min }=5$ days (called critical duration or minimum distance between two successive droughts) constituted one hydrological event. If the time between successive droughts was lesser than the adopted condition $t_{\min }$, then durations of droughts were summed up. Homogene- ity of measurement series is required at searching of probability distributions that describe parameters of events with statistical methods. The Zelanhasič and Salvai (1987) model used to identification of probability distributions of maximum droughts takes up only single observation - the maximum drought from individual hydrological years or half-years. This is the reason that statistical non-homogeneity of annual series of maximum deficits of summer droughts and their maximum durations set up in the scheme of hydrological years was investigated using two non-parametric tests: RankSum and Spearman's Rho. The tests chosen are proposed as the most useful in researching non-homogeneity of hydrological measurement series (Ozga-Zieliński 1987). The droughts from the period 1963-2010 showed to be non-homogenous, however after shortening the observation period (the first year left off) the homogeneity of series was already preserved, at the significance level 0.1 . Jakubowski $(2005 ; 2006)$ underlines a distinct statistical non-homogeneity of droughts, supposing then that the estimation of distributions of characteristics of maximum droughts should be carried out for each half-year separately.

Winter and summer droughts are two separate phenomena of different genesis (Zielińska 1964). Jakubowski (2006) explains the non-homogeneity of droughts saying that just different hydrological processes cause the arising of huge and minor droughts. Many droughts can be skipped due to their lesser parameters in the summer or winter period analysed separately, but such an approach can cause that the investigation of their distributions could be impossible in respect 
to too small numbers of droughts necessary for estimation of drought characteristics.

Distribution of the largest streamflow drought deficit (largest streamflow drought duration) $-H(x)$ of the Zelenhasič and Salvai (1987) model, used in the Nizowka2003 program has got the following form:

$$
H(x)=\operatorname{Pr}(E=0)+\sum_{k=1}^{\infty} F^{k}(x) \operatorname{Pr}(E=k)
$$

where:

$E$ - the number of events in the sequence of years under consideration;

$\operatorname{Pr}(E=k)-$ is the probability that $k$ events would occur during the time interval (e.g. one year, season);

$F(x)$ - distribution function of droughts indices - deficit volume (drought duration).

An estimate of non-exceedance probability $\mathrm{F}(\mathrm{x})$, for the largest event in each time interval is in Nizowka2003 obtained by combining the distribution for the occurrence of events and the distribution for the magnitudes of deficit volume or duration (Tallaksen et al. 2004).

The number of drought events $\mathrm{E}$ occurring in time interval may be represented by Poisson distribution or binomial Pascal distribution. For describing the density function of the second random variable - drought duration or deficit volume, the following distribution functions are proposed: Gamma (Pearson type III), Weibull, Log-Normal, Johnson, Double Exponential, and Generalized Pareto. For estimation of the distribution parameters the method of maximum likelihood has been used. The goodness-of-fit of the distributions is evaluated with the use of the chi-squared test statistic $-\chi^{2}$ (Jakubowski and Radczuk 2004).

The size of maximum deficits and maximum drought durations with defined probability of non-exceedance, obtained from the Nizowka2003 computer program, were standardized for getting relative values, in order to make a comparison of received results with those from other catchments. The maximum deficit was standardized with mean daily runoff, and the maximum drought duration was standardized with mean drought duration estimated for the period 1963 -2010 being under analysis.

\section{RESULTS AND DISCUSSION}

Forty one droughts were observed at the Płachty Stare gauging station, in the Zagożdżonka river catchment, in the multi-annual period 1963-2010; they all concerned the summer half-year, usually months: August, July, June, and September. Though the mean frequency of drought amounted to less than one per year (Tab. 1), meanwhile the years with droughts show a grouping in 2 and 3-year cycles, and even multi-annual ones, the fact being observed already earlier by Kaznowska and Banasik (2009). The 2005-2010 are the last period when the summer drought occurred in each year. After the series of wet years lasting from 1964 up to 1981 (Banasik et al. 2009) the drought has not occurred only in 1985, 1997-1998, 2001 and 2004 (as considered for the period 1982-2010). However several days with the discharge lower than $\mathrm{Q}_{90 \%}$ (Fig. 1) were noted in 2001 and 2004. The mean duration of drought 
TABLE 1. The frequency (numbers) of droughts in the period 1963-2010 in the Zagożdżonka river at Płachty Stare

\begin{tabular}{|l|c|c|c|c|c|c|}
\hline \multirow{2}{*}{} & \multicolumn{5}{|c|}{ Class division in days } & Period \\
\cline { 2 - 7 } & $10-20$ & $21-30$ & $31-60$ & $61-90$ & $\geq 90$ & $1963-2010$ \\
\hline Numbers of droughts & 16 & 6 & 10 & 6 & 3 & 41 \\
\hline \multirow{2}{*}{ Ln } & 0.33 & 0.13 & 0.21 & 0.13 & 0.06 & 0.85 \\
\cline { 2 - 7 } & \multicolumn{2}{|c|}{0.46} & 24 & 15 & 7 & $\sum 100 \%$ \\
\hline
\end{tabular}

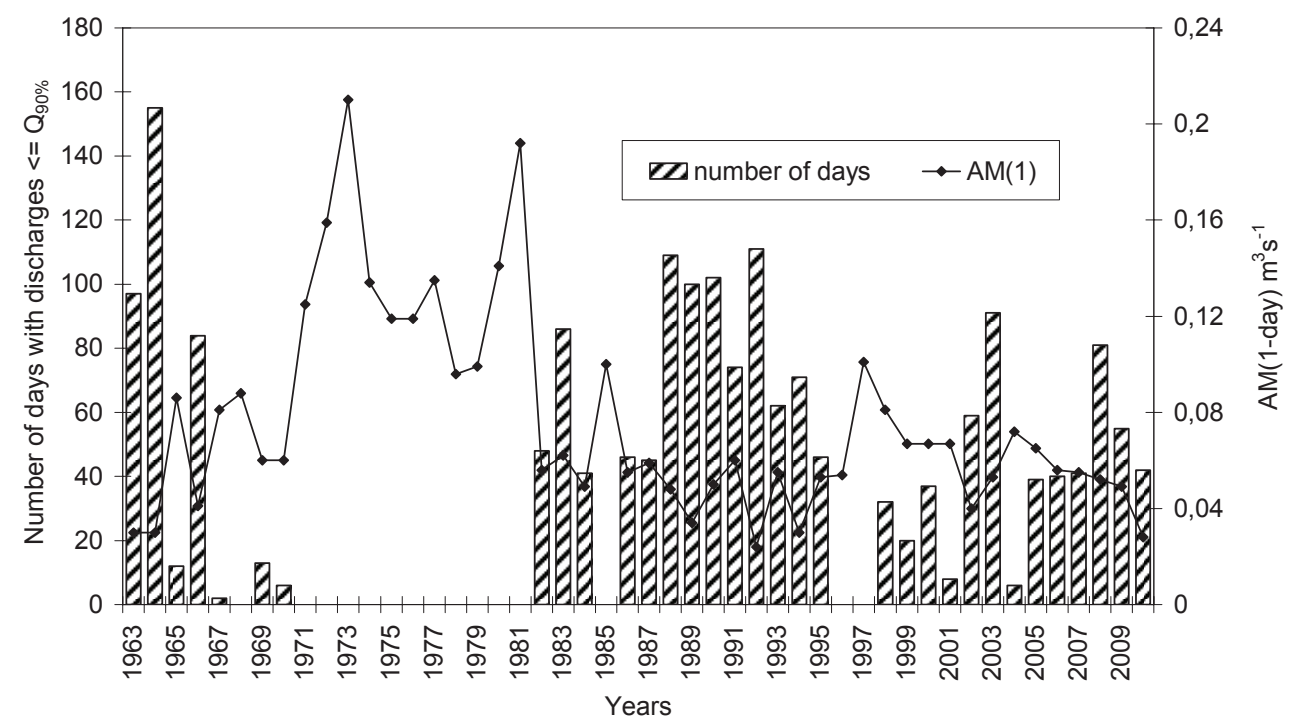

FIGURE 1. Numbers of days with discharges equal or below $\mathrm{Q}_{90 \%}$ and minimal annual discharges sequences in 1963-2010 period, in the Zagożdżonka river at Płachty Stare

truncated with $\mathrm{Q}_{90 \%}$ discharge amounted to about 40 days, and the mean drought deficit amounted to slightly over 70000 $\mathrm{m}^{3}$, this value being less than $1 \%$ of mean yearly runoff. The deficit of the largest volume and duration drought from 1964 (within the multi-annual period under analysis) constituted about $4 \%$ of mean yearly runoff from the Zagożdżonka river catchment (Kaznowska 2011).

Low discharges accompany the occurrence of droughts. The Figure 1 presents the course of minimum annual discharge - AM (1-day) identified within the multi- annual period 1963-2010 under analysis, as correlated with the number of days with discharges equal or lesser than $\mathrm{Q}_{90 \%}$. It was found that not always the lowest from the smallest discharges concern the years containing the greatest number of days with discharges $\leq \mathrm{Q}_{90 \%}$. In the 2010 the lowest discharge amounted to 0.028 $\mathrm{m}^{3} \cdot \mathrm{s}^{-1}$ at the end of July and it was comparable with those from the years 1963, 1964, and 1992 (Fig. 1) characteristic for the extreme hydrological droughts not only in the Zagożdżonka river catchment but also over important areas of Poland. 
Notwithstanding such a low discharge in the Zagożdżonka river, no drought occurred in 2010, being significant for deficit duration and volume; however the mean discharge during that drought was $0.05 \mathrm{~m}^{3} \cdot \mathrm{s}^{-1}$ and it was one of the lowest mean drought discharges recorded up to now (Kaznowska 2011). The linear correlation between the duration of drought and its minimum discharge is weak $\left(\mathrm{R}^{2}=0.23\right)$. A greater correlation was got between the sum of all days with $\leq \mathrm{Q}_{90 \%}$ discharges in individual years of the 1963-2010 period and minimum discharge in a given year of the period under analysis $\left(R^{2}=0.47\right)$. Similarly, a weak linear correlation between the minimum drought discharge and their duration was found by Byczkowski et al. (2002) for selected lowland and mountain rivers of Poland.
Estimation of probability distributions of maximum drought characteristics: maximum deficit and maximum duration was made for summer droughts, being genetically uniform, using the $\mathrm{Ni}$ zowka2003 programme. For preserving statistical uniformity of the series of maximum characteristics the period under study 1963-2010 was shortened by the 1963 and a homogenous series was obtained, necessary for working out trustful statistical research. The number of maximum droughts as a non-continuous function has been described with the Poisson distribution. However the Log-Normal distribution showed to be the theoretic one being best fit to maximum drought deficits, while the Weibull distribution best described maximum durations of droughts in the Zagożdżonka catchment. The Figures 2 and 3 show the fitness of maximum drought character-

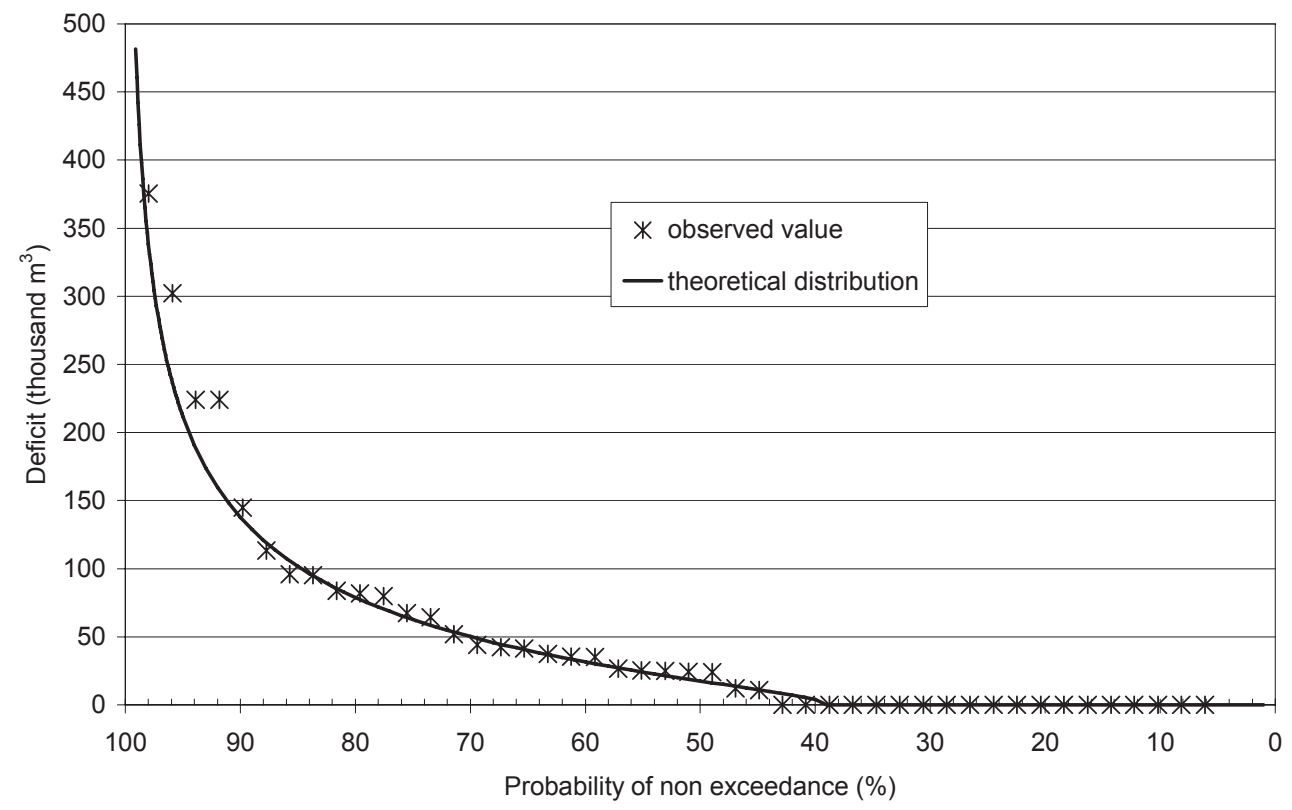

FIGURE 2. Distribution of maximum (largest) summer streamflow droughts deficits volumes, Zagożdżonka river, Płachty Stare gauging station, period 1964-2010 


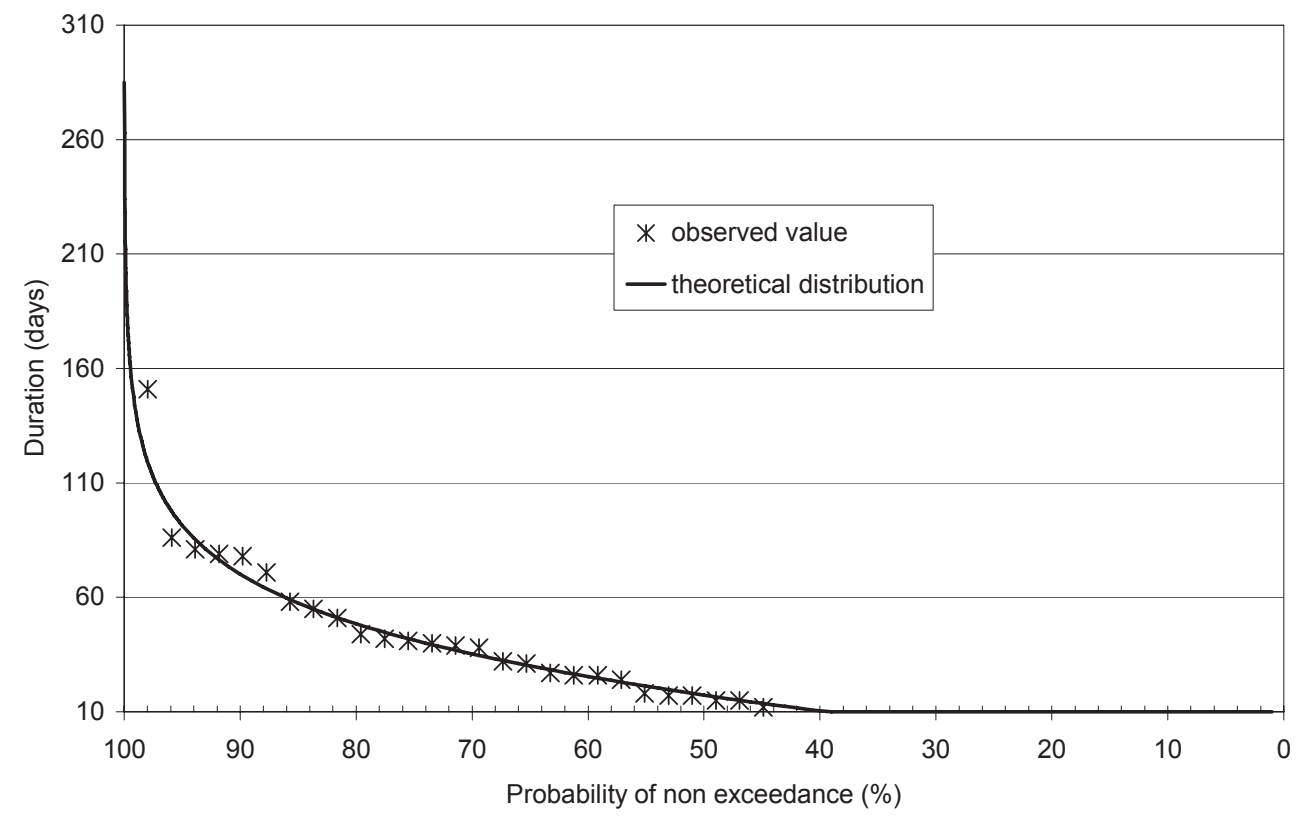

FIGURE 3. Distribution of maximum (largest) summer streamflow droughts duration, Zagożdżonka river, Płachty Stare gauging station, period 1964-2010

istics to their values recorded from the Lowland similarly as the Zagożdżonka Płachty Stare gauging station (one maxi- river. The Log-Normal distribution mum observation from summer half- showed also to be one of the best in the years under study).

The Log-Normal distribution used in the analysis - as one that describe well the random variable (deficit volume of maximum droughts) - confirms the research results obtained by Tokarczyk et al. (2005). The authors mentioned investigated probability distributions of deficits of maximum droughts truncated with the $\mathrm{Q}_{90 \%}$ discharge in subcatchments of the Odra Watershed in Poland. They found that Log-Normal and Generalized Pareto distributions showed to be best fit to maximum drought deficits.

Głogowska (2005) got also the Log-Normal distribution as the best for the maximum drought deficit of the Wilga river catchment situated on the Masovian case of maximum drought deficit for the Linderborg river in Denmark (Fleig et al. 2005), though the Generalized Pareto distribution was evenly good. The results obtained confirm the opinion, since long times spread among hydrology experts, that logarithmed values of hydrological events are fit to normal distribution (Byczkowski 1996). The probability of nonexceedance of the maximum drought observed up to now $\left(\mathrm{V}_{\max , \mathrm{n}}=376000 \mathrm{~m}^{3}\right)$ in the Zagożdżonka river in 1964, that amounts to over 98\% (Tab. 2, Fig. 2) was read out from the obtained curve of probability of maximum deficit. This means that in 98 cases per 100 the deficit of the maximum drought will be lower than that value. The probability of non- 
TABLE 2. Probable largest summer droughts estimated with the use of probability distribution of maximum drought event for the Zagożdżonka river at Płachty Stare

\begin{tabular}{|c|c|c|c|c|c|}
\hline \multirow{2}{*}{$\begin{array}{l}\text { Return } \\
\text { period } \\
T \text { (years) }\end{array}$} & \multirow{2}{*}{$\begin{array}{c}\text { Probability } \\
\text { non } \\
\text { exceedance } \\
p^{\prime}(\%)\end{array}$} & \multicolumn{2}{|c|}{$\begin{array}{c}\text { Maximum deficit volume of } \\
\text { drought }\end{array}$} & \multicolumn{2}{|c|}{ Maximum duration of drought } \\
\hline & & $\begin{array}{c}\text { Deficit } \\
V_{n} \\
\left(10^{3} \cdot \mathrm{m}^{3}\right)\end{array}$ & $\begin{array}{l}\text { Relative deficit } \\
V_{n} / V_{a v .}{ }^{*} \\
(-)\end{array}$ & $\begin{array}{c}\text { Duration } \\
\qquad T_{n} \\
\text { (days) }\end{array}$ & $\begin{array}{c}\text { Relative duration } \\
T_{n} / T_{a v,, n}{ }^{*} \\
(-)\end{array}$ \\
\hline 100 & 99 & 461 & 19.1 & 141 & 3.62 \\
\hline 50 & 98 & 339 & 14.0 & 119 & 3.05 \\
\hline 20 & 95 & 212 & 8.76 & 91 & 2.33 \\
\hline 10 & 90 & 138 & 5.70 & 70 & 1.79 \\
\hline 2 & 50 & 18 & 0.74 & 17 & 0.44 \\
\hline 1.6 & 39 & 0 & 0 & 0 & 0 \\
\hline
\end{tabular}

$* \mathrm{~V}_{\mathrm{av}}-$ mean daily runoff $\left(\mathrm{m}^{3}\right)$ for the period $1963-2010$.

$* \mathrm{~T}_{\mathrm{av}, \mathrm{n}}-$ mean drought duration from period 1963-2010.

exceedance of the maximum duration of drought $\left(\mathrm{T}_{\max , \mathrm{n}}=151\right.$ days $)$ amounts to over $99 \%$ instead (Fig. 3). The deficit of the extreme drought at the Płachty Stare gauging station, that may appear once per 100 years (called here 100year drought) would amount to 460000 $\mathrm{m}^{3}$, and its relative deficit would be 19 times greater than the mean daily runoff, while its duration would be almost 4 times greater than the mean drought duration amounting to $\mathrm{T}_{\mathrm{av}, \mathrm{n} .}=39$ days (Tab. 2). The results obtained for 100 year drought in the Zagożdżonka river are similar to the 100-year drought of the Wilga rivulet situated in the same region of the country (Głogowska 2005); the maximum deficit of the latter being 15 times greater than the mean daily runoff and 4 times longer than the mean drought duration. The drought that may appear more frequently in the Zagożdżonka river catchment - once per 10 years - would have a deficit fairly three times lesser than the 100-year drought, and it would last over slightly two months.
Droughts of small deficits and short durations (17 days; Tab. 2) might appear most often, in every second year; this confirms the results obtained from the analysis of the frequency of droughts in separated classes of drought durations (Tab. 1). Short-lasting droughts of duration up to 20 days (Tab. 1) were characteristic for their highest frequency in the multi-annual period 1963-2010 being under study. The droughts of long duration, lasting more than 3 months were of the least frequency $\left(\mathrm{L}_{\mathrm{n}}=0.06\right)$. The probability of the lack of drought phenomenon $\left(V_{n}=0, T_{n}=0\right)$, that is $39 \%$ (Tab. 2) for the Zagożdżonka catchment, can be read out from the probability distributions selected. The recurrence interval of this probability is $\mathrm{T}=1.6$ years; this means that the drought does not must occur every year, the fact that is concordant with the mean annual frequency of the drought identified for the 1963-2010 period and amounting to less than 1 $\left(L_{n}=0.85\right)($ Tabs 1, 2). 


\section{CONCLUSION}

Duration and deficit volume, as well as frequency of occurrence and probability of occurrence are the most important numerical traits of the drought phenomenon. Their identification is important from the point of view concerning water management, especially on rural areas where water deficits are especially acute. The drought parameters of the Zagożdżonka river were found out on the basis of the analysis of daily discharge hydrographs from the 1963-2010 period. The droughts in the small agricultural catchment under study concern only summer half-years and most often they are of short duration - up to 20 days. Compliance (readiness) of the catchment to the occurrence of such droughts is considerable. The probability of non-exceedance of short (dozen days or so) droughts is about $50 \%$. Longer droughts, lasting lightly over 2 months, can be expected more rarely - once per 10 years. The occurrence of a summer drought lasting almost all the season in the Zagożdżonka river is probable once per 100 years. The duration of observed droughts is not strongly connected with their minimum discharge $\left(Q_{\min , n}\right)$. The value of minimum discharges reached similar dimensions both in the case of long-lasting extreme droughts of 1964 and 1992, and in the case of the short-lasting drought of 2010. This may result from the fact found by Kaznowska and Banasik (2009) that the retention capability of the catchment influences on the magnitude of droughts in the Zagożdżonka river at a greater extent than do the climatic conditions. This conclusion confirms the research by Kasprzyk (2010) who states that pro- longed lack-of-precipitation periods decide on duration of droughts, while the traits of surface and underground catchments decide on their intensity.

\section{Acknowledgment}

The paper has been prepared with financial support by a grant from Iceland, Liechtenstein and Norway through the EEA Financial Mechanism and the Norwegian Financial Mechanism and Resource for Sciences (2008-2011), and by Polish Ministry of Sciences and Higher Education. The support provided by these organizations is gratefully acknowledged.

\section{REFERENCES}

BANASIK K. BYCZKOWSKI A., HEJDUK L., GŁADECKI J. 2009: Changes in rainfall and runoff from a small lowland river basin in Poland based on long term records. International workshop on status and perspectives of hydrology in small basins: Goslar-Hahnenklee, Federal Republic of Germany, 30 March - 2 April 2009, eds. Andreas Herrmann, Sybille Schumann. Clausthal-Zelleerfeld: Papierflieger, 2009, p. 17-20.

BONACCI O. 1993: Hydrological identification of drought. Hydrological Processes, Vol. 7, 249-262.

BYCZKOWSKI A. 1996: Hydrologia, Tom 1 [Hydrology Vol. 1]. WAU Press, Warsaw.

BYCZKOWSKI A., BANASIK K., HEJDUK L., MANDES B. 2001: Wieloletnie tendencje zmian procesów opadu i odpływu w małych zlewniach nizinnych (na przykładzie rzeki Zagożdżonki) [Longterm trend of the rainfall and runoff processes in small river catchment - case study for the Zagożdżonka river). [In:] Dynamika obiegu wody w zlewniach 
rzecznych, pod red. J. Jaworskiego i J. Sekutnickiego (eds.), Polskie Towarzystwo Geofizyczne. IMGW Press Warsaw, 43-52.

BYCZKOWSKI A., MEYER W., GŁOGOWSKA E. [KAZNOWSKA E.] 2002: Analysis of relations between the stream flow of drought parameters according to the different truncation level, 5th ICHE, Vol. V.

CHANG T.J., STENSON J.R. 1990: Is it realistic to define a 100-year drought for water management? Water resources bulletin. American Water Resources Association, Vol. 26, No 5, 823-829.

DE LUIS M., GONZALEZ-HIDALGO J.C., LONGARES L.A., STEPANEK P. 2009: Seasonal precipitation trends in the Mediterranean Iberian Peninsula in second half of 20th century. Int. J. Climatology, 29, 1312-1323.

FARAT R., KĘPIŃSKA-KASPRZAK M., KOWALCZAK P., MAGER P. 1995: Susze na obszarze Polski w latach 19511990 [Droughts on the area of Poland in the years 1951-1990], Materiaty badawcze IMGW, Seria: Gospodarka Wodna i Ochrona Wód, no 16.

FLEIG A.K., TALLAKSEN L.M., HISDAL H., DEMUTH S. 2005: A global evaluation of streamflow drought characteristics. Hydrol. Earth Syst. Sci. Discuss., 2, 2428-2464.

GŁOGOWSKA E. [KAZNOWSKA E.] 2005: Występowanie niżówek w zlewniach o odmiennych warunkach fizycznogeograficznych [The occurrence of streamflow droughts in the physical-geographical conditions of river catchments]. Unpublished Ph.D. thesis, Warsaw, Warsaw Agricultural University.

GÓRSKI T. 2007: Changes in Poland's agroclimatic conditions over the last century. Papers on GLOBAL CHANGE, Polish Academy of Sciences Warsaw, no 14, $55-67$.

HONG W., LENN-KIAT S., ASHOK S., XUN-HONG CH. 2007: Trend Analysis of Streamflow Drought Events in Ne- braska. Water Resour Manage, Springer Science+Business Media B.V.

JAKUBOWSKI W. 2005: Rozkłady prawdopodobieństwa niżówek maksymalnych [Distributions of low flow maximus]. Przegląd Geofizyczny, Zeszyt 3-4, 229-248 [Engl. summ.].

JAKUBOWSKI W. 2006: An application of the Bivariate Generalized Pareto Distribution for the probabilities of low flow extremes estimation. Hydrol. Earth Syst. Sci. Discuss., 3, 859-893.

JAKUBOWSKI W., RADCZUK L. 2004: NIZOWKA2003 software, in Tallaksen, L.M. and van Lanen, H.A.J. (eds.), Hydrological Drought. Processes and Estimation Methods for Streamflow and Groundwater, Development in Water Sciences, 48, CD-Appendix, Elsevier, Amsterdam.

KASPRZYK A. 2010: Prawdopodobieństwo wystapienia niżówek w zlewniach rzek województwa świętokrzyskiego [Low flows probability of occurrence in the Świętokrzyskie Province river catchment]. In: Woda w badaniach geograficznych (red.): Ciupa T., Suligowski R. (eds.), Instytut Geografii Uniwersytet J. Kochanowskiego, Kielce, 273-280.

KAZNOWSKA E. 2011: Analysis of low flow characteristics and drought frequency in agricultural catchments. (In press).

KAZNOWSKA E., BANASIK K. 2009: Ocena intensywności niżówek rzecznych w małej zlewni rolniczej Niziny Mazowieckiej w ostatnich 45 latach [Intensity of streamflow droughts in small agricultural catchment of Mazowiecka Lowland in last 45 years]. Acta Scientiarum Polonorum. Formatko Circumiectus, 8 (3-4), 5-16 [Engl. summ.]

KAZNOWSKA E., HEJDUK L. 2011: Ocena wybranych charakterystyk ilościowych i jakościowych okresów bezwezbraniowych w rzece Zagożdzonce [Evaluation of selected characteristics of quantitative and qualitative periods without floods in the Zagożdżonka River]. Przegląd Naukowy Inżynierii i Kształtowania Śro- 
dowiska [Scientific Review Engineering and Environmental Science] In Press. [Engl. summ.].

KUNDZEWICZ Z., SZWED M., PIŃSKWAR I., RADZIEJEWSKI $M$. 2007: Global change and extreme hydrological events. Papers on GLOBAL CHANGE, Polish Academy of Sciences Warsaw, no 14, 79-92.

KUNDZEWICZ Z., ZALEWSKI M., KĘDZIORA A., PIERZGALSKI E. 2010: Zagrożenia związane $\mathrm{z}$ wodą [Water - related threats]. Nauka $\mathrm{nr}$ 4, 87-96.

LORENC H., MIERKIEWICZ M., SASIM M. 2008: Susze w Polsce ze szczególny uwzględnieniem roku 2006 (historia, przyczyny, natężenie, zasięg, skutki, wnioski). [Drought in Poland from special regard year 2006 (history, causes, intensity, range, results, conclusions)]. Wiadomości IMGW, Tom II (LII) Zeszyt 1-2, 3-32 [Engl. summ.]

ŁABĘDZKI L. 2006: Susze rolnicze: zarys problematyki oraz metody monitorowania i klasyfikacji [Agricultural droughts an outline of problems and methods of monitoring and classification]. Woda Środ. Obsz. Wiej., Rozpr. Nauk. Monogr. 17, IMUZ Falenty [Engl. summ.]

ŁABĘDZKI L. 2009: Expected development of irrigation in Poland in the context of climate change. Journal of Water and Land Development, No 13b, 17-29.

OZGA-ZIELIŃSKA M. 1990: Niżówki i wezbrania - ich definiowanie i modelowanie [Droughts and floods - their definition and modelling]. Przeglad geofizyczny, 35, 1-2

OZGA-ZIELIŃSKI B. 1987: Badanie statystycznej niejednorodności ciągów pomiarowych [Estimation of statistical non-homogeneity of the data series], Gospodarka Wodna nr 10, 226-228.

STAHL K., HISDAL H., HANNAFORD J., TALLAKSEN L.M., VAN LANEN H.A.J., SAUQUET E., DEMUTH S., FENEDEKOVA M., JÓDAR J. 2010: Streamflow trends in Europe: evidence from a dataset of near-natural catch- ments. Hydrol. Earth Syst. Sci. Discuss, 7, 5769-5804.

TALLAKSEN L.M., VAN LANEN H.A.J. (eds.) 2004: Hydrological Drought. Processes and Estimation Methods for Streamflow and Groundwater, Development in Water Sciences, 48.

TALLAKSEN L.M., MADSEN H., HISDAL H. 2004: Frequence Analysis. [In:] Tallaksen, L.M. and van Lanen, H.A.J. (eds.) Hydrological Drought. Processes and Estimation Methods for Streamflow and Groundwater, Development in Water Sciences, 48, 199-271.

TOKARCZYK T., DUBICKIA., KUPCZYK E., SULIGOWSKI R. 2005: Assessment of drought potential risk for Upper and Middle Odra Watershed. Geophysical Research Abstracts, Vol. 7.

WIENCLAW E., ZŁOTOSZEWSKA-NIEDZIAŁEK H., CIEPIELOWSKI A. 1993: Warunki hydrologiczne zlewni rzeki Zagożdzonki [Hydrological condiction of Zagożdzonka catchment], Przegląd Wydziału Melioracji i Inżynierii SGGW, Zeszyt 2, 25-37

YOUNG K., MORSE G.K., SCRIMSHAW M.D., KINNIBURGH J.H., MACLEOD C.L., LESTER J.N. 1999: The relation between phosphorus and eutrophication in the Thames catchment. UK. The Science of the Total Environment 228: 157-183.

ZIELIŃSKA M. 1964: Metody obliczania i prognozowania niżówek w ujęciu probabilistycznym [The methods of determination and forcast of low water] Wiadomości Stużby Hyd.i Meteor. Z 58, 31-57 [Engl. summ.].

ZELENHASIČ E., SALVAI A. 1987. A method of streamflow drought analysis. Water Resources Research, Vol. 23, No 1, 156-168.

Streszczenie: Niżówki i prawdopodobieństwo ich wystepowania $w$ małej zlewni rolniczej. Celem pracy jest ilościowa analiza występowania zjawiska niżówki i prawdopodobieństwa jej występowania w małej zlewni rolniczej, na podstawie 
długoletniej serii obserwacji przepływów dobowych rzeki Zagożdżonki w profilu Płachty Stare, w kontekście śledzenia zmian w reżimie rzeki w wieloleciu 1963-2010. Zlewnia rzeki Zagożdżonki jest jedną z kilku w Polsce, która posiada długi ciąg pomiarów wartości opadów i odpływu. Na potrzeby wyznaczenia niżówek na hydrogramach dobowych przepływów użyto poziomu odcięcia $\mathrm{Q}_{90 \%}$ (przepływ odczytany krzywej czasów trwania przepływów). Dodatkowym kryterium w wyodrębnieniu niżówek zastosowano minimalny czas trwania zjawiska wynoszący 10 dni. Do wyznaczenia rozkładów prawdopodobieństwa objętości deficytu i czasu trwania niżówek maksymalnych letnich dla rzeki Zagożdżonki użyto programu Nizowka2003. Niźówki w rozpatrywanej małej rolniczej zlewni dotyczą jedynie półrocza letniego i najczęściej trwają krótko - do 20 dni. Raz na 10 lat można spodziewać się niżówek dłuższych, trwających niewiele ponad 2 miesiące. Raz na 100 lat jest prawdopodobne wystapienie w rzece Zagożdżonce niżówki letniej trwającej prawie przez cały sezon. Pomiędzy minimalnym przepływem niżówek a ich czasem trwania uzyskano słabą zależność.

Słowa kluczowe: niżówka, susza hydrologiczna, prawdopodobieństwo nieprzewyższenia

MS. received May 2011

\section{Authors' address:}

Katedra Inżynierii Wodnej-SGGW

ul. Nowoursynowska 159

02-776 Warszawa

ewa_kaznowska@sggw.pl

kazimierz_banasik@sggw.pl 